\title{
Review on Phase Change Materials with Nanoparticle in Engineering Applications
}

\author{
C. Kaviarasu ${ }^{1, *}$ and D. Prakash ${ }^{2}$ \\ ${ }^{1 *}$ Department of Mechanical Engineering, Arasu Engineering College, Kumbakonam, Tamilnadu, India. \\ ${ }^{2}$ School of Mechanical Engineering, SASTRA University, Thanjavur, Tamilnadu, India. \\ Received 11 February 2016; Accepted 7 September 2016
}

\begin{abstract}
Phase change materials (PCMs) with their phenomenal phase changing behavior hold a key for many developments in renewable energy and engineering systems for sustainable future. PCM which can store and release heat energy over a temperature range has become an eminent candidate for many engineering applications that includes thermal, civil, electronics and textile. In modern days, Nano-PCMs have gained much attention of the engineers in utilizing them for thermal energy storage systems, for cooling microelectronic systems, for space heating or cooling in modern buildings and also in smart textiles for human comfort. Contribution of Nano-PCM based energy systems in energy savings and reduction of global gas emission is of interest now. This review provides an outlook of various types of PCM, choices of nanomaterial for incorporation and applications of nanomaterial incorporated PCMs. The most common types of PCM used are water, paraffin, hydrated salts and bio based PCM. Despite their high latent heat storage advantage, their low thermal property calls for the incorporation of nanomaterials. Nanomaterials with their high surface to volume ratio tune the thermal properties of the base PCM. Nanomaterials used for incorporation in PCM include $\mathrm{Al}, \mathrm{Cu}, \mathrm{SiO} 2, \mathrm{TiO} 2$, Carbon nanotubes (CNT), Carbon nanofibers (CNF), Al2O3, $\mathrm{NaOH} \mathrm{KOH} \mathrm{etc.}$
\end{abstract}

Keywords: Phase Change Materials, Nanoparticles, Thermal Energy Storage, Minichannel heat sink, Zero-energy buildings and Smart textiles.

\section{Introduction}

Abundance of renewable energies available in nature should be harnessed and utilized to meet the growing power demand for sustained future. Renewable energy systems play a vital role in energy savings and reduction of global gas emission to have a pollution free environment for future generations. Solar energy claims to be the primary source among various renewable energy sources which is intermittent and uncertain by its nature. Hence forth a need arises to develop thermal storage systems to store the available excess energy for later use. Thermal energy storage system should possess good storage capacity, high efficiency, quick charging/discharging, cost effective, and hazard free [1]. Phase change materials (PCM) with their heat storage and releasing behavior have found suitable for latent heat storage systems that can be operated at wide range of temperatures. High energy process of PCMs (latent heat of vaporization) is not preferred due to their large density changes which need additional support equipments. Hence, latent heat of fusion of PCMs is utilized for thermal applications. Latent heat storage of PCMs has high energy density when compared to their sensible heat storage. Latent heat of fusion and melting temperature of the PCMs are the important criteria for choosing them for a specific application. The melting and solidification of a PCM is shown in Fig.1.

Different types of PCMs like water-based, salt hydrates, paraffin and vegetable-based are of interest in recent days.

\footnotetext{
*E-mail address: kaviarasumech@aec.org.in

ISSN: $1791-2377$ @ 2016 Eastern Macedonia and Thrace Institute of Technology. All rights reserved.
}

However, their properties like thermal conductivity and diffusivity are remarkably very poor [2]. Z. Youssef et al. reviewed on various PCMs for their interesting characteristics, tunable thermophysical properties and flow behaviors to understand and utilize them for thermal applications. Microencapsulated PCM Slurry (MPCMS) and PCM Emulsions (PCMEs) undergo phase transition in a positive temperature range. PCME have shown good stability and flow properties, while MPCMS with low viscosity could solve the pumping power requirements. In case of shape-stabilized PCM slurries (SPCMSs) being immiscible in the transport fluid and confinement to the porous structure is a major concern [3]. Incorporation of nanomaterials could possibly increase the thermal conductivity of the PCMs with their high surface area to volume ratio. Aluminum oxide $\left(\mathrm{Al}_{2} \mathrm{O}_{3}\right)$, copper $(\mathrm{Cu})$, copper oxide $(\mathrm{CuO})$, gold $(\mathrm{Au})$, silver $(\mathrm{Ag})$, silicon carbide $(\mathrm{SiC})$, titanium carbide (TiC), titanium oxide $\left(\mathrm{TiO}_{2}\right)$, and carbon nanotubes were some of the nanoparticles used for thermal applications [4]. Nanoparticles can be fabricated by any one of the following techniques like mechanical ball milling, chemical precipitation, inert-gas-condensation technique, spray pyrolisis, and thermal spraying [5]. M.A. Kibria et al. explored some of the nanoparticle enhanced PCMs for thermal energy storage systems. The review was focused on fatty acid and paraffin based PCMs enhanced with the addition of nanomaterials like carbon nanotubes (CNT), carbon nanofiber (CNF), graphite and graphene nanoparticles, metal and metal oxide nanoparticles. CNT and CNF enhanced PCMs with surface treatment have shown better enhancement in thermal conductivity. Thermal conductivity improvement for metal and metal oxide PCMs were size, shape and concentration dependent. More 
dispersion of nanoparticles in PCM may cause an increase in mass/volume concentration that in turn causes a negative impact (dynamic viscosity increases). Further investigation is needed in determining an optimum level of nanoparticles concentration at which the thermal conductivity increases with minimal decrement in heat storage capacity of the PCMs [6]. Applications of Nano-PCMs in thermal energy storage systems (TES), Microelectronics cooling, Zeroenergy buildings and Smart textiles for thermal comfort were highlighted in this review.

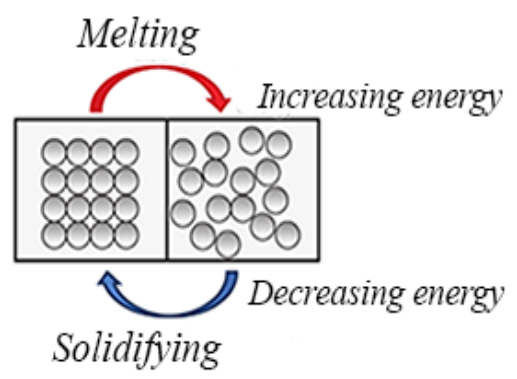

Fig. 1. Melting and Solidification process of PCM [2].

Different types of PCMs like water-based, salt hydrates, paraffin and vegetable-based are of interest in recent days. However, their properties like thermal conductivity and diffusivity are remarkably very poor [2]. Z. Youssef et al. reviewed on various PCMs for their interesting characteristics, tunable thermophysical properties and flow behaviors to understand and utilize them for thermal applications. Microencapsulated PCM Slurry (MPCMS) and PCM Emulsions (PCMEs) undergo phase transition in a positive temperature range. PCME have shown good stability and flow properties, while MPCMS with low viscosity could solve the pumping power requirements. In case of shape-stabilized PCM slurries (SPCMSs) being immiscible in the transport fluid and confinement to the porous structure is a major concern [3]. Incorporation of nanomaterials could possibly increase the thermal conductivity of the PCMs with their high surface area to volume ratio. Aluminum oxide $\left(\mathrm{Al}_{2} \mathrm{O}_{3}\right)$, copper $(\mathrm{Cu})$, copper oxide $(\mathrm{CuO})$, gold $(\mathrm{Au})$, silver $(\mathrm{Ag})$, silicon carbide $(\mathrm{SiC})$, titanium carbide (TiC), titanium oxide $\left(\mathrm{TiO}_{2}\right)$, and carbon nanotubes were some of the nanoparticles used for thermal applications [4]. Nanoparticles can be fabricated by any one of the following techniques like mechanical ball milling, chemical precipitation, inert-gas-condensation technique, spray pyrolisis, and thermal spraying [5]. M.A. Kibria et al. explored some of the nanoparticle enhanced PCMs for thermal energy storage systems. The review was focused on fatty acid and paraffin based PCMs enhanced with the addition of nanomaterials like carbon nanotubes (CNT), carbon nanofiber (CNF), graphite and graphene nanoparticles, metal and metal oxide nanoparticles. CNT and $\mathrm{CNF}$ enhanced PCMs with surface treatment have shown better enhancement in thermal conductivity. Thermal conductivity improvement for metal and metal oxide PCMs were size, shape and concentration dependent. More dispersion of nanoparticles in PCM may cause an increase in mass/volume concentration that in turn causes a negative impact (dynamic viscosity increases). Further investigation is needed in determining an optimum level of nanoparticles concentration at which the thermal conductivity increases with minimal decrement in heat storage capacity of the
PCMs [6]. Applications of Nano-PCMs in thermal energy storage systems (TES), Microelectronics cooling, Zeroenergy buildings and Smart textiles for thermal comfort were highlighted in this review.

\section{Thermal Energy Storage Systems}

Thermal energy systems (TES) conserve thermal energy in the form of sensible or latent heat that can be utilized later for many domestic and industrial applications. Sensible heat storage systems are less expensive but constrained with storage capacity. Latent heat storage using PCMs have drawn much attention and emphasis in enhancing their thermal characteristics have become the recent trends. PCMs with high energy density can store and release excess energy but still most of them possess low thermal conductivity that leads to a lag in heat transfer rate. Addition of nanomaterials will improve the conductivity of PCMs and enhance their thermal performance. In this section, effective applications of Nanoparticle enhanced PCMs, Nanofluid based PCMs, Micro/Nano encapsulated PCMs and shape-stabilized PCMs in thermal energy systems were summarized [7, 8]. The Fig.2 shows some example for thermal energy storage systems which are used for both domestic and industrial applications.

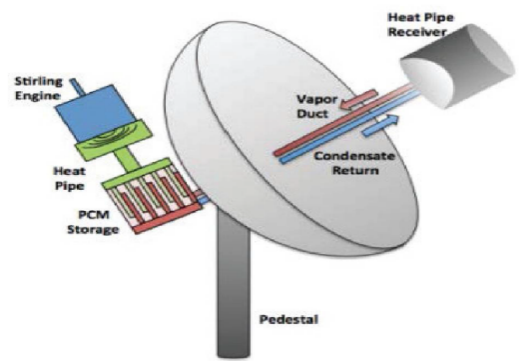

a) Latent energy storage system for dish striling power generation
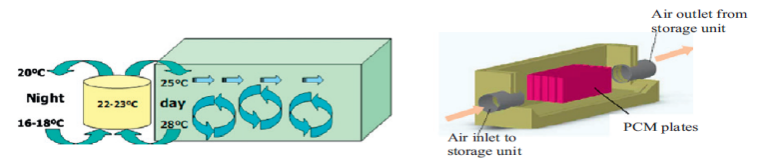

b) PCM in free cooling systems

Fig. 2. Nano/PCM based thermal energy storage systems [24-25].

A. A. Altohamy et al. investigated the effect of $\gamma$ $\mathrm{Al}_{2} \mathrm{O}_{3}$ /water nanofluid PCM in a spherical capsule LHTES system. Ethylene glycol solution act as the heat transfer fluid, to add or remove heat from the $\gamma-\mathrm{Al}_{2} \mathrm{O}_{3} /$ water nanofluid PCM that is contained in the spherical capsule. Addition of the nanoparticle accelerates the solidification process and increases the energy storing capacity of the PCM. Increase in volume of nanoparticle in NFPCM reduces the solidification time by $30 \%$ [9]. Z. Rao et al. carried out a molecular dynamic simulation of two different PCM system models, one with nano-encapsulated and other with nanoparticle enhanced for heat and mass transfer analysis. Nano-encapsulated PCM uses n-octadecane $\left(\mathrm{C}_{18} \mathrm{H}_{38}\right)$ as core material and $\mathrm{SiO}_{2}$ as shell material. The self diffusion property of encapsulated PCM increases with increase in temperature and decrease in shell thickness. In case of Nano-PCM, Al-nanoparticle is mixed with nnonadecane to form nanoparticle enhanced PCM system. In solid state, the self diffusion coefficient of the Nanoparticle 
enhanced PCM system increases with decrease in diameter of Al-nanoparticle [10]. S. Yu et al. enhanced the thermal conductivity of the Bio based PCM using carbon nanomaterial for thermal energy conservation systems. Graphite nano platelets (xGnp) and Carbon nanotubes (CNT) are added as composites to the bio-based PCM separately to form $\mathrm{xGnP} /$ bio-based PCM and CNT/bio-based PCM. For 5 wt. \% addition of carbon nanomaterials the

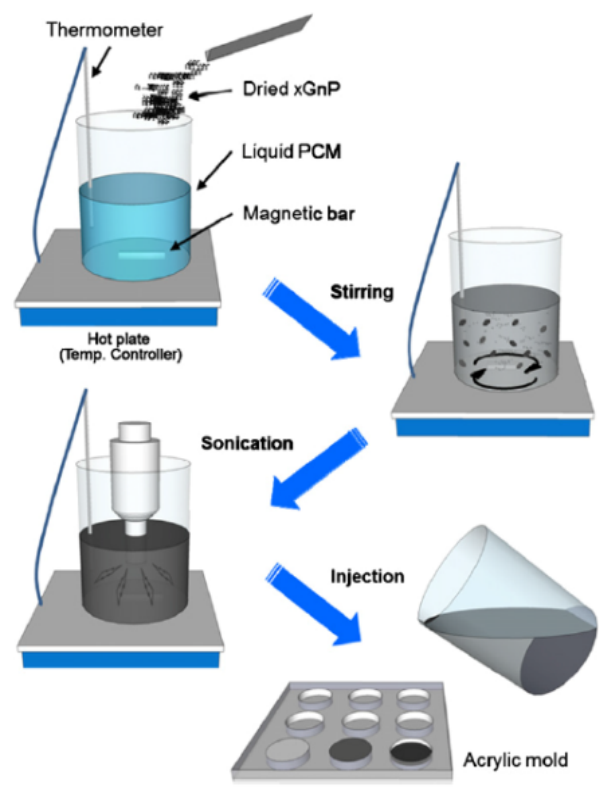

a) Composite PCM loaded with $x$ Gnp thermal conductivity is increased by $336 \%$ for $\mathrm{xGnP} /$ biobased PCM and $166 \%$ for CNT/bio-based PCM respectively. This positive result hinders the application of these Biobased PCM/CNT composites in thermal energy storage systems. The fabrication method of the bio-based PCM is shown in Fig. 3b [11].

Fig. 3. Fabrication of nanomaterials incorporated PCMs (Nano-PCMs) [11, 52].

Shuying $\mathrm{Wu}$ et al. compared the temperature distribution rate for ordinary paraffin nanofluid PCM with Cu-paraffin nanofluid PCM. It was observed that the melting rate for cuparaffin is higher than that of the ordinary paraffin which is due to the enhancement in thermal conductivity of paraffin PCM by addition of the cu-nanoparticles with uniform shape and size [12]. C.-J. Ho et al. compared the forced convection heat transfer process between $\mathrm{Al}_{2} \mathrm{O}_{3}$ /water nanofluid and MEPCM suspensions in water, in a circular tube heated at constant rate. Thermal conductivity of $\mathrm{Al}_{2} \mathrm{O}_{3}$ /water nanofluid was increased with a slight decrease in heat capacity, but for PCM suspensions the opposite trend was observed. When compared to nanofluid, PCM suspensions have shown better contribution in suppressing the surface wall temperature. Forced convection cooling processes using both the coolants were highly depending on the flow rate and friction factor [13]. As a hybrid coolant, combined benefits of increase in specific heat capacity and thermal conductivity offered by both MEPCM particle and $\mathrm{Al}_{2} \mathrm{O}_{3}$ nanoparticles will improve the cooling performance. But pressure drop due to increased viscosity of this hybrid coolant is a major challenge. Hence, optimizing the flow properties of coolant to reduce its viscosity will help a lot in balancing the pressure drop and make the thermal system energy efficient [14]. S. Mossaz et al. studied the influence of Nanofluid PCM slurry in convective heat transfer application. Nanofluid PCM slurry, with high apparent heat capacity during phase change enhances the specific heat and thermal conductivity which really progress the convection heat transfer process. THERMINOL 66 is the base fluid and $\mathrm{NaOH} \mathrm{KOH}$ salt was the added nanoparticles. The flow rate has no influence on small size particle since the melting time will be more but for large size particle they play a major role. Increase in volume concentration and mass concentration increases the viscosity and specific heat respectively. Encapsulation is strongly recommended to avoid corrosion, agglomeration and deposition of these suspended particles [15].

V. Kumaresan et al. investigated the solidification nature of the NFPCM prepared by dispersing MWCNT in deionized water (DI) at different volume concentrations of MWCNT $(0.15 \%, 0.30 \%, 0.45 \%$ and $0.6 \%)$. The solidification time was reduced by $14 \%$ and $20.1 \%$ for a volume concentration of $0.6 \%$ at a surface temperature of $-9{ }^{\circ} \mathrm{C}$ and $-12{ }^{\circ} \mathrm{C}$ respectively. The MWCNT also played as a nucleating agent. Energy conservation up to $9 \%$ was predicted in this experiment for the chiller integrated with the CTES system using the NFPCM [16]. X. Fang et al. studied the thermal conduction behavior of Graphite nanosheets/eicosane composites PCM at different cooling rate. When cooling rate was increased from 2.03 to $30.94{ }^{0} \mathrm{C} / \mathrm{min}$, the thermal conductivity was decreased by $25 \%$ for PCM composite composed of graphite nanosheets (1 wt. $\%$ ). Later on for increased volume concentration (for a max. of 5 wt. \%) of graphite nanosheets (GNS-30) the solid-state thermal conductivity was increased linearly to a maximum value of $1.57 \mathrm{~W} / \mathrm{m} \mathrm{K}$. [17]. Omar Sanusi et al. investigated the thermal enhancement in paraffin PCM by adding graphite nanofiber (GNFs). A comparative study was made between paraffin and GNFs/paraffin PCMs in aluminum made thermal containment units (TCUs) with different geometry. It was witnessed that the solidification time was reduced by $61 \%$ for GNFs/paraffin PCMs over the ordinary paraffin [18]. L. Jia et al. studied the phase transition properties of $\mathrm{TiO}_{2} /$ water 
nanofluid for their applications in cold thermal energy storage (CTES) systems. The influence of mass concentration of $\mathrm{TiO}_{2}$ nanoparticles and cooling rate on the phase transition properties like, phase transition temperature $\left(\mathrm{T}_{\mathrm{o}}\right)$, Phase transition time $(\mathrm{t})$ and enthalpy $(\Delta \mathrm{H})$ were studied. For a certain cooling rate, with increased mass concentration of $\mathrm{TiO}_{2}$ nanoparticles, phase transition properties increases at first and then decreases. The same phenomenon was observed with low cooling rate better than at high cooling rate [19]. N. Javani et al. designed a new latent heat storage system for cooling batteries in electric vehicles. The conventional shell and tube heat exchanger cannot meet the cooling demand for hybrid electric vehicle even though employed with PCMs due to low thermal conductivity. To overcome this, CNT incorporated PCM was employed in the heat exchanger for effective performance. The study concluded that increase in CNT concentration and CNT series connections in PCM reduces the tube length and enhance the heat transfer. Smaller tube diameter reduces the tube length but results in a pressure drop penalty [20]. M. Nabavitabatabayi et al. performed a numerical analysis to examine the effect of nanoparticles enhanced PCM in a domestic hot water tank. The operational parameters like nanoparticle concentration, amount of PCM, mass flow rate have their impact in the thermal performance of the hot water tank. $\mathrm{Cu}$ nanoparticles with volumetric concentration of $10 \%$ in sodium acetate PCM reduces the solidification time by $60 \%$. The thermal inertia of the enhanced PCM prevents the temperature drop in water to some extent. This reveals that the nanoparticles in PCM enhances the performance of hot water tank and reduces the power consumption [21]. A. Zabalegui et al. made a study on thermal storage and latent heat reduction mechanism in NFPCM for thermal storage systems and residential heating. MWCNTs were dispersed in liquid paraffin to form NFPCM. For small diameter nanoparticles in the suspensions, the rate of latent heat reduction corresponding to particle volume fraction increases in magnitude due to the effects of Brownian movement, interfacial liquid layering and particle cluster. In addition, micro-scale particles shown a better performance in thermal storage compared to nano-scale particles. However, further study has to be made for different nanofluid materials for storage performance validation [22]. R. Hossain et al. reported the thermal performance of an energy storage system containing Aluminum foam porous medium in which "Cyclohexane+CuO" nanoparticles confined to the void space. The melting process and heat transfer phenomena of the Nano-PCM in a rectangular container storage system was studied. A substantial movement in the PCM melting front was influenced by the porous medium while the nanoparticle had no impact. For low porosity of the porous medium and high volume concentration of the nanoparticle, the rate of melting of Nano-PCM was faster. Nano-PCM contained in a high porous medium consumes more heat energy for melting compared to a low porous medium [23].

\section{Microelectronics cooling using Nano-PCMs in MCHS}

Miniaturization in modern electronics leads to high heat generation in computer systems which call for an advancement in cooling techniques. The microchannel heat sink (MCHS) cooling application was first brought to light by Tuckerman and Pease in 1981 [26]. Since then many researches were done in channel material, its design, coolant types and cooling methodologies for the betterment of MCHS in cooling electronic systems. MCHS can be fabricated by micro-milling, micro-molding, silicon etching or electroplating techniques
[27]. MCHS employs either a direct cooling (a direct contact between heated surface and coolant) or an indirect cooling method (a metallic layer that conduct heat away from heated surface to the coolant) [28, 29]. MCHS often uses liquid coolants whose properties play a vital role in heat transfer performance. Nanofluids with enhanced conductionconvection heat transfer properties have drawn much attention to replace the ordinary coolants. The contribution of nanoparticle size, shape, volume concentration, thermal conductivity of particles and base fluid properties in MCHS systems performance were revealed for continuous improvement in cooling applications [30, 31, and 32]. Nanofluid and nanoparticle enhanced PCMs with good thermophysical properties and high heat storage capacity have emerged as an advanced coolant for high tech cooling applications in microelectronics and other thermal management systems.
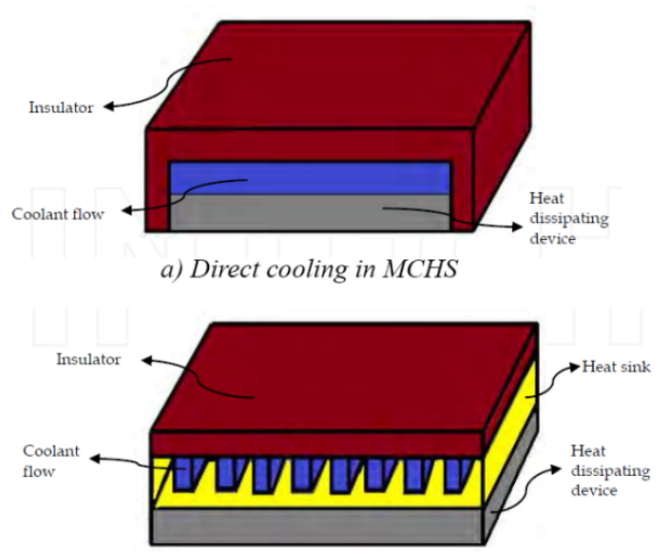

b) Indirect cooling in MCHS
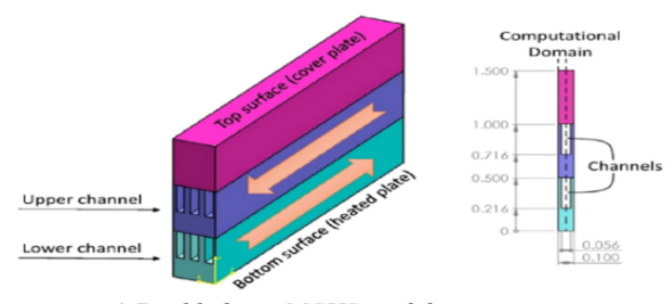

c) Double layer MCHS model

Fig. 4. Microelectronics cooling using PCM in MCHS [28-29, 35].

Fig. 4 shows the direct cooling, indirect cooling and double layer model of MCHS in which Nano-PCMs are used for microelectronics cooling. C. J. Ho et al. conducted an experimental study to measure thermal and hydraulic performance of the MCHS system using MEPCM particles/water as coolants. For Reynolds number $\left(\mathrm{Re}_{\mathrm{bf}}\right) 133$ and latent-sensible heat ratio $\left(\omega_{\text {pcm }} / \mathrm{Ste}_{\mathrm{bf}}\right) \quad 0.0472$, heat transfer rate was enhanced by $52 \%$. Low flow rate and low latent-sensible heat ratio has enhanced the system performance. However, the use of these advanced coolants invites the need for pump source to balance the pressure drop due to enhanced viscosity and friction factor [33]. The application of $\mathrm{Al}_{2} \mathrm{O}_{3}$-water nanofluid and/or MEPCM particles as a hybrid coolant for cooling MCHS was also studied by C. J. Ho et al. The heat transfer effectiveness highly depends on amount of particle dispersed in base fluid, flow rate and latent-sensible heat ratio. For high Reynolds number, convective heat transfer effectiveness for $\mathrm{Al}_{2} \mathrm{O}_{3}-$ water nanofluids was noticed better than the hybrid coolant 
since the convection efficacy of hybrid coolant was outplayed by the pressure drop due enhanced viscosity [34]. B. Rajabifar modeled a double layer counter flow MCHS to study its hydraulic and thermal performance using DI water, nanofluid and NEPCM slurries as coolants. From the study, it was observed by combining the usage of NEPCM in lower layer and Nanofluids in upper layer as coolants with a 0.2/.04 volumetric concentration respectively, the cooling and flow performance of the MCHS system was enhanced [35]. A. B. S. Alquaity et al. developed a homogenous fluid model composed of lauric acid nanoparticles in water and investigated the laminar flow effect in micro channels for electronics cooling applications. For $10 \%$ volume concentration of nanoparticles, the effectiveness ratio, performance index and merit number were attained a maximum value of $2.75,1.67$ and 0.64 respectively. This parametric study shows an enhancement in heat transfer properties of PCMs which make it suitable for electronics cooling applications [36].

J. Tigner et al. performed a demonstration and analysis of an aluminum based model with cartridge heater as heat source to study the effective cooling methods for microelectronics devices. The thermal platform was cooled by three different methods using ambient air, paraffin PCM and $\mathrm{CuO} /$ paraffin $\mathrm{PCM}$. The surface temperature of the platform was reduced by $12 \mathrm{~K}$ using paraffin PCM and by $15 \mathrm{~K}$ using $\mathrm{CuO} /$ paraffin $\mathrm{PCM}$ when compared to ambient air cooling method. In addition the model also suggested that smaller platform will show better thermal response compared to larger one [37]. R. Pakrouh et al. performed a numerical investigation to optimize the design parameters of a PCM based pin-fin heat sink using Taguchi algorithm for electronics cooling application. Paraffin RT44HC was chosen as PCM material while aluminum is chosen for pin and heat sink base. The geometrical parameters considered

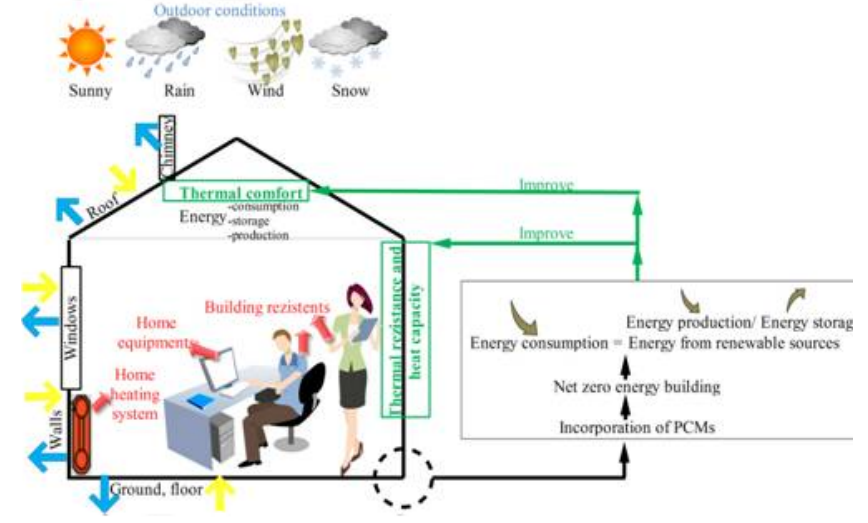

a) Thermodynamic systems for building
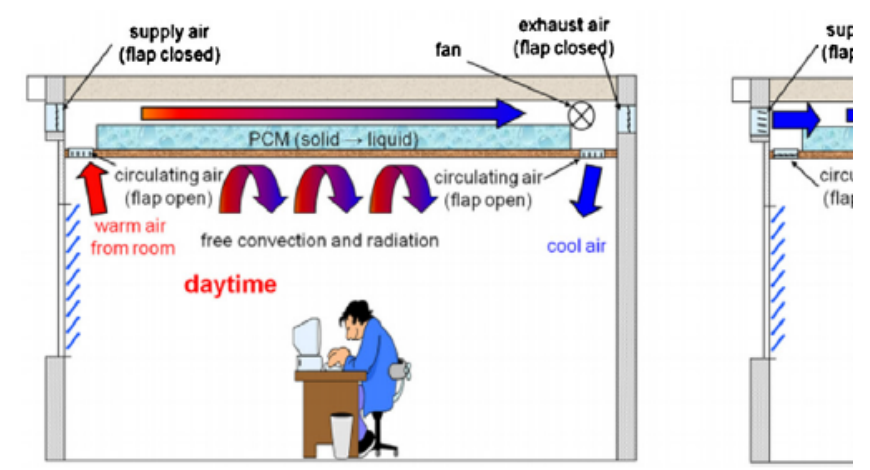

c) Ventilated cooling ceiling with PCM at day and night ti: Fig. 5. Nano/PCM applications for thermal comfort in modern buildings $[40,49$ and 50]. here include number, height and thickness of pin-fin, sink base thickness, critical operating temperature and the PCM volume percentage. The optimum PCM percentage was found to be $60.61 \%$ for 100 pin fin with heat sink thickness $4 \mathrm{~mm}$ operating for the critical temperature of $50{ }^{\circ} \mathrm{C}$ [38]. S.A. Nada et al. made a parametric study on CF/PCM module which includes different carbon foam (CF) structures with different porosities and conductivities, PCMs with different thermal conductivities, fusion temperature and fusion heat, module geometrical parameters and module power densities to suggest the best combination of CF/PCM for cooling enhancement. CF porosity and CF module height are directly proportional to the module temperature. CF/PCM module with high CF skeleton thermal conductivity can defy peak power density and ensure safe operation. High latent heat and low fusion temperature of PCM in CF/PCM module is the best opted for thermal management systems at cyclic power operation [39].

\section{Thermal comfort in modern buildings using Nano- PCMs}

Electrical energy being spent for space heating and cooling systems in buildings for human comfort leads to energy crisis. Renewable energy harness and utilization make way for the concept of net zero-energy building and zero-carbon emission environment [46]. One such attempt is the application of Nano-PCMs for modern building in heating, ventilation and air conditioning systems (HVAC). NanoPCMs possess the ability to store and release energy during their phase change as when employed as heat transfer fluids in thermal energy systems [48]. Nano-PCMs are also used as composites for building materials like cement, mortar etc. with remarkable thermal and mechanical properties [47].

Fig. 5 shows some potential applications of Nanomaterials and PCMs in modern buildings. J. O. Carneiro et al. evaluated the thermal effect of $\mathrm{TiO}_{2}$ nanoparticles coated mortar brick masonry wall in space cooling for modern buildings. Thermal conduction resistance and thermal transmission co-efficient for the $\mathrm{TiO}_{2}$-coated mortar wall were reduced by $10 \%$ and $13 \%$ respectively. The water evaporation was improved by $136 \%$ by coating $\mathrm{TiO}_{2}$ nanoparticles to mortar wall surface [40]. The thermal property of $\mathrm{TiO}_{2}$-paraffin wax composite PCM material was studied by $\mathrm{J}$. Wang et al. $\mathrm{TiO}_{2}$ in Paraffin wax influences the phase change temperature and latent heat capacity of the PCM material. For less than 1\% loading of $\mathrm{TiO}_{2}$, the phase change temperature decreases with increase in the latent heat capacity of the PCM and the opposite scenario for more than $2 \%$ loading of $\mathrm{TiO}_{2}$. In both solidsolid phase and solid-liquid phase of the composite PCM at $0.7 \%$ loading, the latent heat value attained a peak value of $20.1 \mathrm{~J} / \mathrm{g}$. With increase in $\mathrm{TiO}_{2}$ particle, thermal conductivity of the composite PCM increases. When the composite PCM is in complete liquid state the thermal conductivity decreases with increase in temperature [41]. R. Parameshwaran et al. developed a new VAV-NTES A/C system for modern buildings to achieve thermal comfort, indoor air quality and energy saving. Silver nanoparticle enhanced the thermal storage of PCM and also facilitated the chiller plant to operate at low power capacity for energy savings in buildings. The combination of air ventilation techniques and silver nanoparticle enhanced thermal energy storage (NTES), reduced the power consumption on a year-round basis. The VAV-NTES A/C system, achieved $36-58 \%$ of 
energy saving on peak day and for single day energy saving is of $24-51 \%$ [42]. S. Harikrishnan et al. investigated the effect of adding $\mathrm{TiO}_{2}, \mathrm{ZnO}$ and $\mathrm{CuO}$ nanoparticles separately to the lauric acid (LA) and stearic acid (SA) mixture composite PCM. A remarkable increase in thermal conductivity and good thermal stability were attained by the composite PCM for $1 \mathrm{wt} \%$ addition of nanoparticles. $\mathrm{TiO}_{2}$ and $\mathrm{ZnO}$ nanoparticles increased the thermal conductivity of the composite PCM by $34.85 \%$ and $46.97 \%$ respectively. The $\mathrm{CuO}$ nanoparticles increased the thermal conductivity by $62.12 \%$ for the composite PCM and it is suggested as the best option for building heating applications [43]. J. Jeon et al. prepared three composite PCMs made from octadecane, hexadecane and paraffin as base material to which exfoliated graphite nanoplatelets (xGnP) were added to enhance building heating application. The fabrication of such composite PCM is shown in Fig. 3a. Thermal conductivity increases with increasing $\mathrm{xGnp}$ concentration. For $5 \mathrm{wt} \%$ addition of $\mathrm{xGnp}$ in octadecane/xGnP composite PCM the thermal conductivity was enhanced by $101 \%$. Similarly, for each sample $3 \mathrm{wt} \%$ addition of xGnp improved the thermal conductivity by $76 \%$. This suggests the potential applications of these composite PCMs in space heating for modern buildings [44].

S. Kamali reviewed the free cooling application of PCMs for modern building. Various PCM systems like flat plate trapped RT25, floor-coupled ventilation system, PCM packed-bed thermal storage, and heat pipes incorporated into the PCM storage were currently used. Reduction in $\mathrm{CO}_{2}$ emissions by $9 \%$ when compared to conventional ventilation systems encourage the use of PCM based free cooling system for pollution free environment [45]. M. Thambidurai et al. reviewed the potential applications and standards in selection of PCMs for free cooling of buildings. PCM temperature range, PCM container design, subcooling, cooling degree days and air flow rate are the major criteria while selecting PCMs. Free cooling system's effectiveness is determined by optimum melting temperature with high heat storage capacity of the PCM. For developing a cost effective free cooling system, greater importance should be given to types of PCM, materials for encapsulating PCM, air passage channel and package [46]. Y. Konuklu et al. reviewed the importance of PCM microencapsulation for energy efficient buildings. When PCM integrated to buildings without encapsulation will face problems like leakage from wall surface, chemical composition change during humid climates and low viscous melted hydro carbon diffusion over building materials. Microencapsulated PCMs can be incorporated with building materials like cement mixtures and mortars, wallboards, gypsum plaster Sandwich, panels and slabs. Thermal capacity of the building materials increases while the compressive strength and density decreases. New buildings with light weight structure can be built using low density Microencapsulated PCMs building materials for avoiding environmental impacts like $\mathrm{CO}_{2}$ emissions. Further investigation is needed in thermal storage performance of Microencapsulated PCM buildings in real conditions for economic and environmental benefits [47]. An investigation in viscosity, heat transfer coefficients and pressure loss for various nanofluids was carried out by D. P. Kulkarni et al. for their application in heating buildings during cold climate. $\mathrm{CuO}, \mathrm{Al}_{2} \mathrm{O}_{3}$ and $\mathrm{SiO}_{2}$ nanoparticles were dispersed to the binary base fluid ethylene glycol/ water mixture. The Viscosity of nanofluids decreases with increase in temperature and increases with increase in volume concentration of nanoparticles. Heat transfer coefficient increases with increase in volume concentration of nanoparticles. $\mathrm{CuO}$ nanofluid achieved high heat transfer coefficient, high viscosity and high pressure loss when compared with that of $\mathrm{Al}_{2} \mathrm{O}_{3}$ and $\mathrm{SiO}_{2}$ nanofluids. In building heating systems for same heat transfer rate, the volume flow rate, mass flow rate and pumping power can be reduced by nanofluids when compared to conventional heat transfer fluids [48].

\section{Smart textiles}

Smart and intelligent textiles acclimatize automatically to the environmental changes in order to provide thermal comfort to humans. Such a thermo-regulated textile uses PCMs to act smartly to keep the human body warm/cool depending on the environmental temperature. PCMs in the form of packs and capsules with their phase changing phenomena stores and release heat energy have drawn much attention for developing smart textiles. Fiber technology, coating, lamination, micro and nano encapsulation methods found suitable for incorporation of PCMs in textiles. Importance should be given in choosing PCM type, quantity of PCM to be used, its latent heat, melting temperature, crystallization temperature and the area covered by PCM on human body [51, 52 and 53]. Types of PCMs and their potential applications in developing thermo-regulated smart clothes for human comfort were reviewed by S. Mondal. The review highlighted the incorporation of nanomaterials enhanced PCMs in textiles by coating, lamination and fiber technology. Importance of micro and nano encapsulation for PCM to avoid leakage over clothes surface during phase change was suggested. Challenges in fabricating smart textiles with thermal stability, durability, industrial policies and marketing were also reviewed. Practical applications of smart textiles in sportswear, space clothes, bed accessories and medical clothes were acknowledged [54]. Composite thermochromic and thermo-regulating PCM (CTPCM) for fabricating thermal comfort fabrics was prepared by S. Yi et al. using sol-gel method. CTPCM composed of bromocresolpurple, boric acid and tetradecyl alcohol was embedded in 3-D silicone gel network to prevent the PCM from oozing out during the phase change (solid -liquid) as it melts. The CTPCM composite with heat storage capacity of $158.25 \mathrm{~J} / \mathrm{g}$ and phase change temperature of $40.92{ }^{\circ} \mathrm{C}$ was coated to the fabrics. The CTPCM treated fabrics had shown good thermal properties and thermochromic manners [55]. MEPCMs using n-octadecane as core material and Melamine Formaldehyde as shell are prepared and incorporated to polypropylene fibre for fabricating melt spun thermo comfort fabrics was reported by K. Iqbal and D. Sun. For $12 \%$ incorporation of MEPCM, the latent heat capacity for the polypropylene fibre was observed as $9.2 \mathrm{~J} / \mathrm{g}$. Predicted model and experimental results were well correlated for the thermo regulated fabric in terms of its latent heat, tenacity and modulus [56]. M.S. Tjønna ${ }^{\circ}$ s et al. compared the cooling effect of melt spun PCM fibres with Glauber's salt PCM packs on thermal manikin. A high cooling effect for a short period of time was observed for PCM fibre compared to PCM packs. The cooling effects of the PCM fibres rely on the amount of area it covers where as the cooling duration rely on latent heat of fusion and mass. The difference between PCM fibres melting temperature and the operation temperature is the key for the cooling efficiency of the PCM fibres [57]. Nanoencapsulated PCM using paraffin wax and UF as the core and shell materials 
was prepared by M. Karthikeyan et al. through in situ polymerization process. Nanocapsules with an average size of $260 \mathrm{~nm}$ were coated over the cotton fabric by pad-drycure method. Nanocapsules with latent heat of fusion of 74.2 $\mathrm{J} / \mathrm{g}$ and melting temperature of $64.30{ }^{0} \mathrm{C}$ had good thermal stability. For cotton fabric with 20 wt. $\%$ and 40 wt. $\%$ coating of nanocapsules, the heat storage capacity is of 1.52 and $1.91 \mathrm{~J} / \mathrm{g}$ respectively. The tensile strength, water absorption and abrasion resistance of the coated cotton fabric got improved [58].

\section{6. $\mathrm{PCM} /$ Nanomaterials Properties}

Table 1 Thermo physical properties of PCM

\begin{tabular}{|c|c|c|c|c|c|c|}
\hline \multirow[b]{2}{*}{ Authors } & \multirow[b]{2}{*}{ PCMs } & \multicolumn{5}{|c|}{ Thermo Physical Properties of PCMs } \\
\hline & & $\begin{array}{l}\text { Thermal } \\
\text { conductivity } \\
\text { "k" in } \\
(\mathbf{W} / \mathbf{m} \mathbf{K}) \\
\end{array}$ & \begin{tabular}{|l|} 
Density “ $\rho "$ \\
in \\
$\left(\mathrm{kg} / \mathrm{m}^{3}\right)$
\end{tabular} & $\begin{array}{l}\text { Specific heat } \\
\text { capacity " } C_{\mathrm{p}} \text { " in } \\
(\mathrm{J} / \mathrm{kg} \mathrm{K})\end{array}$ & $\begin{array}{l}\text { Latent heat of } \\
\text { fusion " } \mathrm{L}_{\mathrm{h}} \text { " in } \\
(\mathrm{J} / \mathrm{kg})\end{array}$ & $\begin{array}{l}\text { Melting temp. } \\
\text { " } T_{m} \text { " in (K) }\end{array}$ \\
\hline A.A. Altohamy et al. [9] & Water & 0.561 & 999.84 & $4.182 \times 10^{3}$ & $334 \times 10^{3}$ & 273.15 \\
\hline S. Yu et al. [11] & Bio-based PCM & 0.2 & 860 & -- & $149.2 \times 10^{3}$ & 301.28 \\
\hline Shuying Wu et al. [12] & Paraffin & 0.2699 & 900 & $2.95 \times 10^{3}$ & $205.6 \times 10^{3}$ & $329-333$ \\
\hline \multirow{2}{*}{ C.J. Ho et al. [13] } & Water & 0.62 & 997 & $4.17 \times 10^{3}$ & $333 \times 10^{3}$ & 273.15 \\
\hline & $\begin{array}{l}\text { Microencapsulated } \\
\text { PCM }\end{array}$ & 0.31 & 961.4 & $2.13 \times 10^{3}$ & -- & 309.55 \\
\hline S. Mossaz et al. [15] & THERMINOL 66 & 117.6 & 1007.1 & $1.6269 \times 10^{3}$ & -- & $--\cdot$ \\
\hline O. Sanusi et al. [18] & n-tricosane & 0.2 (solid) & 796.9 & $156.7 \times 10^{3}$ & $2.2 \times 10^{5}$ & $329.15 \pm 2$ \\
\hline \multirow{2}{*}{ X.L. Wang et al. [84] } & \multirow{2}{*}{$\begin{array}{l}\text { C-L Acid } \\
\text { material code } \\
{[\mathrm{C} 0.14]}\end{array}$} & 0.375 (solid) & \multirow{2}{*}{870.8} & $1.853 \times 10^{3}($ solid $)$ & \multirow{2}{*}{$100.1 \times 10^{3}$} & \multirow{2}{*}{--} \\
\hline & & 0.372 (liquid) & & $1.891 \times 10^{3}$ (liquid) & & \\
\hline \multirow{2}{*}{ A. Zabalegui et al. [22] } & \multirow{2}{*}{ Paraffin } & 0.21 (solid) & 900 (solid) & 1888 (solid) & \multirow{2}{*}{$1.8 \times 10^{5}$} & \multirow{2}{*}{326} \\
\hline & & 0.12 (liauid) & 780 (liquid) & 2272 (liquid) & & \\
\hline R. Hossain et al. [23] & $\begin{array}{l}\text { Liquid } \\
\text { Cyclohexane }\end{array}$ & 0.127 & 779 & $1.763 \times 10^{3}$ & $32.557 \times 10^{3}$ & -- \\
\hline B. Rajabifar [35] & $\begin{array}{l}\text { Nanoencapsulated } \\
\text { n-octadecane } \\
\text { PCM }\end{array}$ & 0.18 & 815 & $2 \times 10^{3}$ & $244 \times 10^{3}$ & -- \\
\hline A.B.S. Alquaity et al. [36] & $\begin{array}{l}\text { Nanosized lauric } \\
\text { acid PCM } \\
\text { Particle }\end{array}$ & 0.147 & 1007 & $1.76 \times 10^{3}$ & $211 \times 10^{3}$ & -- \\
\hline R. Pakrouh et al. [38] & Paraffin RT44 & 0.2 & 780 (solid) & $2 \times 10^{3}$ & $255 \times 10^{3}$ & $314.15-318.15$ \\
\hline M. Karthikeyan et al. [58] & $\begin{array}{l}\text { Nanoencapsulated } \\
\text { paraffin }\end{array}$ & -- & -- & --- & $74.2 \times 10^{3}$ & 337.45 \\
\hline \multirow[t]{2}{*}{ S. Wi et al. [59] } & $\begin{array}{l}\text { Coconut oil } \\
\text { SSPCM }\end{array}$ & 0.321 & $-\cdots$ & $-\cdot$ & $110.4 \times 10^{3}$ & 299.93 \\
\hline & Palm oil SSPCM & 0.2891 & $-\cdots$ & $-\cdots$ & $127.3 \times 10^{3}$ & 290.41 \\
\hline $\begin{array}{l}\text { A.O.Elsayed [60] } \\
\text { D.K.Benson et al. [61] }\end{array}$ & $\begin{array}{l}\text { Neopentyl-glycol } \\
\text { PCM }\end{array}$ & 0.25 & 1046 & $2.76 \times 10^{3}$ & $131 \times 10^{3}$ & $313.15-316.15$ \\
\hline \multirow{2}{*}{$\begin{array}{l}\text { A. Castell and } \\
\text { M.M. Farid [62] }\end{array}$} & $\begin{array}{l}\text { RT } 21 \text { PCM } \\
\text { incorporated } \\
\text { gypsum board } \\
\text { (PCMGB). }\end{array}$ & 0.2 & 893 & $1.34 \times 10^{3}$ & $34 \times 10^{3}$ & $291.15-296.15$ \\
\hline & $\begin{array}{l}\text { Macro } \\
\text { encapsulated } \\
\text { SP-25 A8 }\end{array}$ & 0.6 & 1380 & $2.5 \times 10^{3}$ & $180 \times 10^{3}$ & $288.15-303.15$ \\
\hline \multirow[b]{2}{*}{$\begin{array}{l}\text { K. Nithyanandam and R. } \\
\text { Pitchumani }[63]\end{array}$} & $\begin{array}{l}\mathrm{Li}_{2} \mathrm{CO}_{3}(35 \%)- \\
\mathrm{Na}_{2} \mathrm{CO}_{3}(65 \%)\end{array}$ & 1.89 & 2260 & $1.64 \times 10^{3}$ & $344 \times 10^{3}$ & 778.15 \\
\hline & $\begin{array}{l}\mathrm{Li}_{2} \mathrm{CO}_{3}(32 \%)- \\
\mathrm{K}_{2} \mathrm{CO}_{3}(35 \%)- \\
\mathrm{Na}_{2} \mathrm{CO}_{3}(33 \%) \\
\end{array}$ & 2.02 & 2260 & $1.65 \times 10^{3}$ & $276 \times 10^{3}$ & 670.15 \\
\hline
\end{tabular}

Thermophysical properties of the PCMs like thermal conductivity, density, specific heat capacity, latent heat of fusion and melting temperature were listed in Tab. 1. Latent heat of fusion and melting temperature were the important criteria for the PCM selection. In Tab. 2, thermophysical properties of nanomaterials like density, specific heat capacity and thermal conductivity were listed. Thermal conductivity of nanomaterials plays a vital role in enhancing the conductivity of PCMs. Tab. 3 lists the thermophysical properties of Nano-PCMs and Tab. 4 lists the various applications of PCMs. 
Table 2 Thermophysical properties of Nanomaterials

\begin{tabular}{|c|c|c|c|c|}
\hline \multirow[b]{2}{*}{ Authors } & \multirow[b]{2}{*}{ Nanomaterials } & \multicolumn{3}{|c|}{ Thermophysical Properties } \\
\hline & & $\begin{array}{c}\text { Bulk density } \\
\left(\mathrm{kg} / \mathrm{m}^{3}\right)\end{array}$ & $\begin{array}{c}\text { Thermal conductivity } \\
(\mathbf{W} / \mathbf{m} \mathbf{K})\end{array}$ & $\begin{array}{c}\text { Specific heat capacity } \\
(\mathrm{J} / \mathrm{kg} \mathrm{K})\end{array}$ \\
\hline S. Wi et al. [59] & $\mathrm{xGnp}$ & $5.3 \times 10^{-6}-1 \times 10^{-5}$ & $2-300$ & 710 \\
\hline A. Sciacovelli et al. [64] & $\begin{array}{c}\mathrm{Cu} \\
(\text { Avg. dia. } 15 \mathrm{~nm})\end{array}$ & 8954 & 400 & 383 \\
\hline H. Peng et al. [65] & $\begin{array}{c}\text { A1 } \\
(\text { Avg. dia. } 20 \mathrm{~nm})\end{array}$ & 2688 & 237 & 905 \\
\hline \multirow[b]{2}{*}{ A. Adil et al. [66] } & $\begin{array}{c}\mathrm{SiO}_{2} \\
\text { (Avg. dia. } 12 \mathrm{~nm})\end{array}$ & 2200 & 1.38 & 773 \\
\hline & $\begin{array}{c}\mathrm{TiO}_{2} \\
\text { (Avg. dia. } 20 \mathrm{~nm})\end{array}$ & 4156 & 8.4 & 692 \\
\hline \multirow{2}{*}{ Hone J [67] } & SWCNT & 2,600 & 6,600 & 425 \\
\hline & MWCNT & 1,600 & 3,000 & 796 \\
\hline L. Fan et al. [68] & $\mathrm{CuO}$ & 6310 & 18 & 540 \\
\hline $\begin{array}{l}\text { Elgafy and Lafdi [69] } \\
\text { Cui et al. [70] }\end{array}$ & CNF & 2260 & 1950 & --- \\
\hline Warzoha et al. [71] & $\begin{array}{c}\text { Herringbone style } \\
\text { graphite } \\
\text { nano fibers }\end{array}$ & 2100 & 25 & -- \\
\hline \multirow{3}{*}{ P. Gunnasegaran et al. [72] } & Diamond & 3510 & 1000 & 497.26 \\
\hline & Ag & 10500 & 429 & 235 \\
\hline & $\mathrm{Al}_{2} \mathrm{O}_{3}$ & 3970 & 40 & 765 \\
\hline Zhong et al. [73] & $\begin{array}{c}\text { Graphene aerogel } \\
\text { (GA) }\end{array}$ & 227 & 2.183 & 1121 \\
\hline
\end{tabular}

Table 3 Thermophysical properties of Nano-PCMs

\begin{tabular}{|c|c|c|c|c|}
\hline Authors & Nano-PCMs & \multicolumn{3}{|c|}{ Thermophysical Properties } \\
\hline \multirow{2}{*}{ S. Yu et al. [11] } & $\begin{array}{l}\text { Bio-based PCM/xGnp } \\
(1,3,5 \text { wt } \%)\end{array}$ & $\begin{array}{c}\mathrm{k} \sim 0.274,0.612, \\
0.670(\mathrm{~W} / \mathrm{m} \mathrm{K})\end{array}$ & $\begin{array}{c}\mathrm{T}_{\mathrm{m}} \sim 304.35,303.75 \\
302.75(\mathrm{~K})\end{array}$ & $\begin{array}{c}\mathrm{L}_{\mathrm{h}} \sim 146.6 \times 10^{3}, 144.5 \times 10^{3}, \\
143.5 \times 10^{3}(\mathrm{~J} / \mathrm{kg})\end{array}$ \\
\hline & $\begin{array}{l}\text { Bio-based PCM/CNT } \\
(1,3,5 \text { wt } \%)\end{array}$ & $\begin{aligned} \mathrm{k} \sim & 0.410,0.490 \\
& 0.536(\mathrm{~W} / \mathrm{m} \mathrm{K})\end{aligned}$ & \begin{tabular}{|c|}
$\mathrm{T}_{\mathrm{m}} \sim 302.35,304.45$ \\
$304.75(\mathrm{~K})$
\end{tabular} & $\begin{array}{c}\mathrm{L}_{\mathrm{h}} \sim 133.4 \times 10^{3}, 132.4 \times 10^{3}, \\
130.1 \times 10^{3}(\mathrm{~J} / \mathrm{kg})\end{array}$ \\
\hline $\begin{array}{l}\text { Shuying Wu et al. } \\
{[12]}\end{array}$ & $\mathrm{Cu} /$ paraffin (1wt \%) & $\begin{array}{l}\mathrm{k} \sim 0.2908(\mathrm{~W} / \mathrm{m} \mathrm{K}) \\
\mathrm{C}_{\mathrm{p}} \sim 2.924 \mathrm{x} 10^{3}(\mathrm{~J} / \mathrm{kg} \mathrm{K}) \\
\rho \sim 908\left(\mathrm{~kg} / \mathrm{m}^{3}\right)\end{array}$ & $\mathrm{T}_{\mathrm{m}} \sim 329-333(\mathrm{~K})$ & $\mathrm{L}_{\mathrm{h}} \sim 183.9 \times 10^{3}(\mathrm{~J} / \mathrm{kg})$ \\
\hline $\begin{array}{l}\text { S. Mossaz et al. } \\
{[15]}\end{array}$ & $\begin{array}{l}\text { Therminol } 66(\mathrm{t} 66) / \mathrm{NaOH} \\
\mathrm{KOH}\end{array}$ & $\begin{aligned} & \mathrm{k} \sim 132.2(\mathrm{~W} / \mathrm{m} \mathrm{K}) \text { at } \\
& 40^{\circ} \mathrm{C} \\
& \rho \sim 1077\left(\mathrm{~kg} / \mathrm{m}^{3}\right) \text { at } \\
& \\
& 20.1^{\circ} \mathrm{C}\end{aligned}$ & -- & $\mu \sim 0.136(\mathrm{~Pa}-\mathrm{s})$ at $20^{\circ} \mathrm{C}$ \\
\hline \multirow{3}{*}{$\begin{array}{l}\text { S. Harikrishnan } \\
\text { et al. [43] }\end{array}$} & $\begin{array}{l}\text { (Lauric acid + stearic } \\
\text { acid) } / \mathrm{TiO}_{2}(1 \mathrm{wt} \%)\end{array}$ & -- & $\begin{array}{l}\mathrm{T}_{\mathrm{m}} \sim 307.58(\mathrm{~K}) \\
\mathrm{T}_{\mathrm{f}} \sim 302.62(\mathrm{~K})\end{array}$ & $\begin{array}{l}\mathrm{L}_{\mathrm{h}} \sim 173.22 \times 10^{3}(\mathrm{~J} / \mathrm{kg}) \\
\mathrm{L}_{\mathrm{hf}} \sim 170.19 \times 10^{3}(\mathrm{~J} / \mathrm{kg})\end{array}$ \\
\hline & $\begin{array}{l}\text { (Lauric acid +stearic } \\
\text { acid) } / \mathrm{ZnO}(1 \mathrm{wt} \%)\end{array}$ & --- & $\begin{array}{l}\mathrm{T}_{\mathrm{m}} \sim 307.62(\mathrm{~K}) \\
\mathrm{T}_{\mathrm{f}} \sim 302.71(\mathrm{~K})\end{array}$ & $\begin{array}{l}\mathrm{L}_{\mathrm{h}} \sim 173.64 \times 10^{3}(\mathrm{~J} / \mathrm{kg}) \\
\mathrm{L}_{\mathrm{hf}} \sim 170.57 \times 10^{3}(\mathrm{~J} / \mathrm{kg})\end{array}$ \\
\hline & $\begin{array}{l}\text { (Lauric acid +stearic } \\
\text { acid)/CuO (1wt \%) }\end{array}$ & --- & $\begin{array}{l}\mathrm{T}_{\mathrm{m}} \sim 307.71(\mathrm{~K}) \\
\mathrm{T}_{\mathrm{f}} \sim 302.77(\mathrm{~K})\end{array}$ & $\begin{array}{l}\mathrm{L}_{\mathrm{h}} \sim 173.86 \times 10^{3}(\mathrm{~J} / \mathrm{kg}) \\
\mathrm{L}_{\mathrm{hf}} \sim 170.08 \times 10^{3}(\mathrm{~J} / \mathrm{kg})\end{array}$ \\
\hline $\begin{array}{l}\text { M. Karthikeyan } \\
\text { et al. [58] }\end{array}$ & Nanoencapsulated paraffin & -- & $\mathrm{T}_{\mathrm{m}} \sim 337.45(\mathrm{~K})$ & $\mathrm{L}_{\mathrm{h}} \sim 74.2 \times 10^{3}(\mathrm{~J} / \mathrm{kg})$ \\
\hline \multirow{2}{*}{ S. Wi et al. [59] } & Coconut oil/xGnp SSPCM & $\mathrm{k} \sim 1.3303(\mathrm{~W} / \mathrm{m} \mathrm{K})$ & $\mathrm{T}_{\mathrm{m}} \sim 300.08(\mathrm{~K})$ & $\mathrm{L}_{\mathrm{h}} \sim 82.34 \times 10^{3}(\mathrm{~J} / \mathrm{kg})$ \\
\hline & Palm oil/xGnp SSPCM & $\mathrm{k} \sim 1.2638(\mathrm{~W} / \mathrm{m} \mathrm{K})$ & $\mathrm{T}_{\mathrm{m}} \sim 291.48(\mathrm{~K})$ & $\mathrm{L}_{\mathrm{h}} \sim 77.18 \times 10^{3}(\mathrm{~J} / \mathrm{kg})$ \\
\hline $\begin{array}{l}\text { A. O. Elsayed } \\
{[60]}\end{array}$ & $(6 \% \mathrm{Al}+6 \% \mathrm{Cu}) / \mathrm{NPG}$ & $\begin{array}{l}\mathrm{k} \sim 0.352(\mathrm{~W} / \mathrm{m} \mathrm{K}) \\
\mathrm{C}_{\mathrm{p}} \sim 1.786 \mathrm{x} 10^{3}(\mathrm{~J} / \mathrm{kg} \mathrm{K}) \\
\rho \sim 1619\left(\mathrm{~kg} / \mathrm{m}^{3}\right)\end{array}$ & -- & $\mathrm{L}_{\mathrm{h}} \sim 74.5 \times 10^{3}(\mathrm{~J} / \mathrm{kg})$ \\
\hline Zhong et al. [73] & $\begin{array}{l}\text { Graphene } \\
\text { aerogel(GA)/Octadecanoic } \\
\text { acid PCM }\end{array}$ & $\mathrm{k} \sim 2.635(\mathrm{~W} / \mathrm{m} \mathrm{K})$ & -- & $\mathrm{L}_{\mathrm{h}} \sim 181.8 \times 10^{3}(\mathrm{~J} / \mathrm{kg})$ \\
\hline Ho C J et al. [74] & $\begin{array}{l}\text { Octadecane } \\
\text { emulsions } / \mathrm{Al}_{2} \mathrm{O}_{3} \\
(0,5,10 \mathrm{wt} \%)\end{array}$ & -- & $\begin{array}{c}\mathrm{T}_{\mathrm{m}} \sim 299.65, \\
299.15, \\
299.45(\mathrm{~K}) \\
\mathrm{T}_{\mathrm{f}} \sim 298.25, \\
298.15, \\
298.45(\mathrm{~K})\end{array}$ & $\begin{array}{rl}\mathrm{L}_{\mathrm{h}} \sim 2 & 243.1 \times 10^{3}, 225.6 \times 10^{3} \\
& 212.3 \times 10^{3}(\mathrm{~J} / \mathrm{kg})\end{array}$ \\
\hline L. Jia et al. [75] & $\mathrm{TiO}_{2}$ Nanofluids & -- & $\mathrm{T}_{\mathrm{m}} \sim 273.45(\mathrm{~K})$ & $\mathrm{L}_{\mathrm{h}} \sim 0.6 \times 10^{3}(\mathrm{~J} / \mathrm{kg})$ \\
\hline
\end{tabular}


Table 4 Applications of Nano-PCMs

\begin{tabular}{|c|c|c|c|}
\hline Authors & Applications & Nanomaterials used & PCMs used \\
\hline A.A. Altohamy et al.[9] & $\begin{array}{l}\text { Nanofluid PCM for CTES } \\
\text { system }\end{array}$ & $\mathrm{Y}-\mathrm{Al}_{2} \mathrm{O}_{3}$ & Water \\
\hline S. Yu et al. [11] & LHTES system & $\mathrm{xGnp} / \mathrm{CNT}$ & Bio-based PCM \\
\hline Shuying Wu et al.[12] & Thermal energy storage & $\mathrm{Cu}$ & Paraffin \\
\hline C.J. Ho et al. [13] & $\begin{array}{l}\text { Advanced Hybrid coolants } \\
\text { for thermal systems }\end{array}$ & $\mathrm{Al}_{2} \mathrm{O}_{3}$ & $\begin{array}{l}\text { n-eicosane MPCM/ } \\
\text { water }\end{array}$ \\
\hline S. Mossaz et al. [15] & Thermal Energy storage & $\mathrm{NaOH} \mathrm{KOH}$ & THERMINOL 66 \\
\hline V. kumaresan et al.[16] & $\begin{array}{l}\text { Cold thermal energy } \\
\text { storage }\end{array}$ & MWCNT & Deionized water(DW) \\
\hline O. Sanusi et al.[18] & Thermal Energy storage & GNF & n-tricosane \\
\hline A. Zabalegui et al. [22] & $\begin{array}{l}\text { Nanofluid based PCM for } \\
\text { LHTES system }\end{array}$ & MWCNT & Paraffin \\
\hline R. Hossain et al. [23] & Thermal Energy storage & $\mathrm{CuO}$ & Liquid Cyclohexane \\
\hline B. Rajabifar [35] & Microelectronics cooling & \multicolumn{2}{|c|}{ Nanoencapsulated n-octadecane PCM } \\
\hline $\begin{array}{r}\text { A.B.S. Alquaity et al. } \\
\text { [36] }\end{array}$ & Microelectronics cooling & \multicolumn{2}{|c|}{ Nanosized lauric acid PCM Particle } \\
\hline J. Tigner et al. [37] & Microelectronics cooling & $\mathrm{CuO}$ nanoparticles & Eicosane $\left(\mathrm{C}_{20} \mathrm{H}_{42}\right)$ \\
\hline $\begin{array}{l}\text { R. Parameshwaran and } \\
\text { S. Kalaiselvam [42] }\end{array}$ & $\begin{array}{l}\text { VAV-NTES A/C system } \\
\text { for building }\end{array}$ & Ag nanoparticles & Water \\
\hline $\begin{array}{r}\text { S. Harikrishnan et al. } \\
{[43]}\end{array}$ & $\begin{array}{l}\text { Building heating } \\
\text { applications }\end{array}$ & $\mathrm{TiO}_{2}, \mathrm{CuO}$ and $\mathrm{ZnO}$ & $\begin{array}{l}\text { Lauric acid/Stearic acid } \\
\text { mixture }\end{array}$ \\
\hline $\begin{array}{r}\text { M. Karthikeyan et al. } \\
{[58]}\end{array}$ & Smart textile & \multicolumn{2}{|l|}{ Nanoencapsulated paraffin } \\
\hline S. Wi et al. [59] & Building materials & $\mathrm{xGnP}$ & $\begin{array}{l}\text { Coconut oil SSPCM } \\
\text { Palm oil SSPCM }\end{array}$ \\
\hline $\begin{array}{l}\text { A.O.Elsayed, [60] } \\
\text { D.K.Benson et al. [61] }\end{array}$ & Latent energy storage & $\mathrm{Al}, \mathrm{Cu}, \mathrm{Sio}_{2}$ and $\mathrm{Tio}_{2}$ & Neopentyl-glycol PCM \\
\hline Zhong et al. [73] & $\begin{array}{l}\text { Thermal management } \\
\text { systems }\end{array}$ & Graphene aerogel (GA) & Octadecanoic acid (OA) \\
\hline L. Jia et al.[75] & $\begin{array}{l}\text { Cold thermal energy } \\
\text { storage }\end{array}$ & $\mathrm{TiO}_{2}$ nanoparticles & Deionized water (DW) \\
\hline Zeng et al.[76] & Energy storage systems & Ag nanoparticles & 1-Tetradecanol $\left(\mathrm{C}_{14} \mathrm{H}_{30} \mathrm{O}\right)$ \\
\hline Sahan and Paksoy [77] & $\begin{array}{l}\text { Solar and thermal energy } \\
\text { storage }\end{array}$ & Nanomagnetite $\left(\mathrm{Fe}_{3} \mathrm{O}_{4}\right)$ & Paraffin \\
\hline Yavari et al. [78] & $\begin{array}{l}\text { Latent heat storage units } \\
\text { for thermal management }\end{array}$ & Graphene & 1-Octadecanol \\
\hline Li et al. [79] & $\begin{array}{l}\text { Cold thermal energy } \\
\text { storage }\end{array}$ & $\mathrm{Cu}$ nanoparticles & Deionized water (DW) \\
\hline M. Mehrali et al. [80] & LHTES system & $\begin{array}{l}\text { nitrogen-doped graphene } \\
\text { (NDG) nanosheets }\end{array}$ & Palmitic acid (PA) \\
\hline al. [81] & $\begin{array}{l}\text { HVAC systems for } \\
\text { buildings. }\end{array}$ & \multicolumn{2}{|c|}{$\begin{array}{l}\text { Nanoencapsulated PCM using } \\
\text { polystyrene as shell and n-octadecane as the core }\end{array}$} \\
\hline J. MacMullen et al.[82] & Energy efficient buildings & $\mathrm{TiO}_{2}$ and $\mathrm{ZnO}$ & $\begin{array}{l}\text { Oil-in-water emulsions } \\
\text { PCM }\end{array}$ \\
\hline Weinstein RD et al.[83] & $\begin{array}{l}\text { Thermal management of } \\
\text { electronics }\end{array}$ & $\begin{array}{l}\text { Graphite nanofibers } \\
\text { (GNF) }\end{array}$ & Paraffin \\
\hline
\end{tabular}

\section{Conclusion}

Nano-PCMs with their combined benefits from latent heat storage of PCMs and high thermal properties of nanomaterials have found applications in modern energy systems to improve their system performance, power savings and contribution

towards reduction of global gas emission. Water, paraffin and fatty acids were commonly used $\mathrm{PCMs}$ in engineering. Nanomaterials like $\mathrm{Al}, \mathrm{Cu}, \mathrm{SiO}_{2}, \mathrm{TiO}_{2}, \mathrm{CNT}, \mathrm{CNF}, \mathrm{Al}_{2} \mathrm{O}_{3}$, $\mathrm{NaOH}-\mathrm{KOH}$ nanoparticles were commonly used for incorporation in PCM which improved their thermophysical 
properties like thermal conductivity, diffusivity, specific heat and latent heat capacity.

1. In thermal energy storage systems (TES), Nano-PCMs were successfully employed and achieved good system performance. The volume concentration of the nanoparticles plays a vital role in enhancing the thermal conductivity of the base PCM. However excessive addition of nanoparticle increases the dynamic viscosity of the fluid which requires more pumping power. Micro or Nano encapsulated PCM with good flow properties could possibly solve the additional pumping power requirements.

2. In microelectronics cooling systems, nanoparticle enhanced PCM and nanofluid PCM were used as coolants in MCHS for cooling applications. Most of the MCHS were made from aluminum in which deionized water or paraffin PCMs incorporated with nanoparticles were used as coolants. Further investigations in optimizing the design geometry of MCHS, choice of nanoparticles and their volume concentration in PCM are required for effective cooling.
3. In modern buildings, application of Nano-PCMs in heating, ventilation and air conditioning systems (HVAC) play a key role in reducing the $\mathrm{CO}_{2}$ emission. Nano-PCMs with their enhanced thermal properties improve the system performance and reduce the power consumption. Nano-PCM coated walls and ceilings for achieving thermal comfort in modern buildings is of practice now. Development of light weight building materials with good thermo- mechanical properties using Nano-PCM as composite in cement and mortar is under investigation.

4. In textile engineering, smart textile or thermo-regulated clothes were developed to acclimatize automatically to the environment changes using Nano-PCMs. Incorporation of Nano-PCMs to textile is carried out by coating, lamination and fiber technology. Micro or Nano encapsulation of PCM is advised to prevent the leakage of melted PCM over the clothe surface. Smart textiles were currently used in sports, space clothes, medical clothes and lab coats. Developing smart textile with good thermal stability and durability over a long period of time is of research now.

\section{References}

1. Kar, Sanjay Kumar. Energy Sustainability Through Green Energy, Green Energy and Technology, Springer India (2015).

2. Fleischer, Amy S. Thermal Energy Storage Using Phase Change Materials: Fundamentals and Applications. Springer, USA (2015).

3. Z. Youssef, A. Delahaye, L. Huang, F. Trinquet, L. Fournaison, C. Pollerberg and C. Doetsch. Energy Conversion and Management, 65, pp.120-132 (2013).

4. V. Trisaksri and S. Wongwises. Renewable and Sustainable Energy Reviews, 11(3), pp. 512-523 (2007).

5. W. Yu, D. M. France, J. L. Routbort and S. U. Choi. Heat Transfer Engineering, 29(5), pp.432-460 (2008).

6. M. A. Kibria, M. R. Anisur, M. H. Mahfuz, R. Saidur and I. H. S. C. Metselaar. Energy Conversion and Management, 95, pp.69-89 (2015).

7. I. Dincer and M. Rosen. Thermal energy storage: systems and applications. John Wiley \& Sons, UK (2002).

8. IEA-ETSAP (Energy Technology Systems Analysis Programme) and IRENA. Thermal Energy Storage, Technology Brief E17, Bonn, Germany (2013).

9. A. A. Altohamy, M. A. Rabbo, R. Y. Sakr and A. A. Attia. Applied Thermal Engineering, 84, pp.331-338 (2015).

10. Z. Rao, S. Wang and F. Peng. International Journal of Heat and Mass Transfer, 66, pp.575-84 (2013).

11. S. Yu, S. G. Jeong, O. Chung and S. Kim. Solar Energy Materials and Solar Cells, 120, pp.549-554 (2014).

12. S. Wu, H. Wang, S. Xiao and D. Zhu. Procedia Engineering, 31, pp.240-244 (2012).

13. C. J. Ho, J. B. Huang, P. S. Tsai and Y. M. Yang. International Journal of Thermal Sciences, 50(5), pp.736-748 (2011).

14. C. J. Ho, J. B. Huang, P. S. Tsai and Y. M. Yang. International Journal of Heat and Mass Transfer, 54(11), pp.2397-2407 (2011).

15. S. Mossaz, J.A. Gruss, S. Ferrouillat, J. Skrzypski, D. Getto, O. Poncelet and P. Berne. Applied Thermal Engineering, 81, pp.388398 (2015).

16. V. Kumaresan, P. Chandrasekaran, M. Nanda, A. K. Maini and R. Velraj. International Journal of Refrigeration, 36(6), pp.1641-1647 (2013).

17. X. Fang, Q. Ding, L. Y. Li, K. S. Moon, C. P. Wong and Z. T. Yu. Energy Conversion and Management, 103, pp.251-258 (2015).

18. O. Sanusi, R. Warzoha and A. S. Fleischer. International Journal of Heat and Mass Transfer, 54(19), pp.4429-4436 (2011).

19. L. Jia, Y. Chen and S. Mo. International Journal of Heat and Mass Transfer, 59, pp.29-34 (2013).

20. N. Javani, I. Dincer and G. F. Naterer. Journal of Power Sources, 268, pp.718-727 (2014).

21. M. Nabavitabatabayi, F. Haghighat, A. Moreau and P. Sra. Applied Energy, 129, pp.253-260 (2014).

22. A. Zabalegui, D. Lokapur and H. Lee. International Journal of Heat and Mass Transfer, 78, pp.1145-1154 (2014).
23. R. Hossain, S. Mahmud, A. Dutta and I. Pop. International Journal of Thermal Sciences, 91, pp.49-58 (2015).

24. [24] C. E. Andraka, A. M. Kruizenga, B. A. Hernandez-Sanchez and E. N. Coker. Energy Procedia, 69, pp.726-736 (2015).

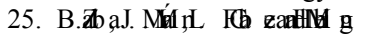
Journal of Refrigeration, 27(8), pp.839-849 (2004).

26. D. B. Tuckerman and R.F.W. Pease. Electron Device Letters, IEEE, 2(5), pp.126-129 (1981).

27. V. P. Gaikwad. IOSR Journal of Mechanical and Civil Engineering, pp.51-57 (2009).

28. P. R. Parida. Doctoral dissertation, Faculty of the Louisiana State University and Agricultural \& Mechanical College In Partial fulfillment of the Requirements for the degree Master of Science in Mechanical Engineering In The Department of Mechanical Engineering, Indian Institute of Technology, Guwahati (2007).

29. I. Mudawar. IEEE Transactions on, 24(2), pp.122-141 (2001).

30. P. S. Lee, S. V. Garimella and D. Liu. International Journal of Heat and Mass Transfer, 48(9), pp.1688-1704 (2005).

31. J. Koo and C. Kleinstreuer. International Journal of Heat and Mass Transfer, 48(13), pp.2652-2661(2005).

32. R. Chein and G. Huang. Applied Thermal Engineering, 25(17), pp.3104-3114 (2005).

33. C. J. Ho, W. C. Chen and W. M. Yan. International Communications in Heat and Mass Transfer, 48, pp.67-72 (2013).

34. C. J. Ho, W. C. Chen and W. M. Yan. International Journal of Heat and Mass Transfer, 69, pp.293-299 (2014).

35. B. Rajabifar. International Journal of Heat and Mass Transfer, 88, pp.627-635 (2015).

36. A. B. Alquaity, S. A. Al-Dini, E. N. Wang and B. S. Yilbas. International Journal of Heat and Fluid Flow, 38, pp.159167 (2012).

37. J. Tigner, M. M. Sedeh, T. Sharpe, A. Bufford and T. Floydmith. Applied Thermal Engineering, 60(1), pp.88-95 (2013).

38. R. Pakrouh, M. J. Hosseini, A. A. Ranjbar and R. Bahrampoury. Energy Conversion and Management, 103, pp.542552 (2015).

39. S. A. Nada and W. G. Alshaer. Energy Conversion and Management, 105, pp.93-102 (2015).

40. J. O. Carneiro, G. Vasconcelos, S. Azevedo, C. Jesus, C. Palha, N. Gomes and V. Teixeira, Energy and Buildings, 81, pp.1-8 (2014).

41. J. Wang, H. Xie, Z. Guo, L. Guan and Y. Li. Applied Thermal Engineering, 73(2), pp.1541-1547 (2014).

42. R. Parameshwaran and S. Kalaiselvam. Energy and Buildings, 69, pp.202-212 (2014).

43. S. Harikrishnan, M. Deenadhayalan and S. Kalaiselvam. Energy Conversion and Management, 86, pp.864-872 (2014).

44. J. Jeon, S. G. Jeong, J. H. Lee, J. Seo and S. Kim. Solar Energy Materials and Solar Cells, 101, pp.51-56 (2012).

45. S. Kamali. Energy and Buildings, 80, pp.131-136 (2014). 
46. M. Thambidurai, K. Panchabikesan and V. Ramalingam. Journal of Energy Storage, 4, pp.74-88 (2015).

47. Y. Konuklu, M. Ostry, H. O. Paksoy and P. Charvat. Energy and Buildings, 106, pp.134-155 (2015).

48. D. P. Kulkarni, D. K. Das and R. S. Vajjha. Applied Energy, 86(12), pp.2566-2573 (2009).

49. N. Soares, J. J. Costa, A. R. Gaspar and P. Santos. Energy and buildings, 59, pp.82-103 (2013).

50. H. Weinläder, W. Körner and B. Strieder. Energy and Buildings, 82, pp.65-72 (2014).

51. F. Wang and C. Gao eds. Protective clothing: Managing thermal stress, Elsevier, UK (2014).

52. N. Pan and G. Sun eds. Functional textiles for improved performance, protection and health, Elsevier, UK (2011).

53. L. F. Cabeza ed. Advances in thermal energy storage systems: Methods and applications. Elsevier (2014).

54. S. Mondal. Applied Thermal Engineering, 28(11), pp.1536-1550 (2008).

55. S. Yi, S. Sun, Y. Deng and S. Feng. The Journal of The Textile Institute, 106(10), pp.1071-1077 (2015).

56. K. Iqbal and D. Sun. Renewable Energy, 71, pp.473-479 (2014).

57. M. S. Tjønnås, H. Færevik, M. Sandsund and R. E. Reinertsen. Ergonomics, 58(3), pp.535-542 (2015).

58. M. Karthikeyan, T. Ramachandran and O. L. Shanmugasundaram. The Journal of The Textile Institute, 105(12), pp.1279-1286 (2014).

59. S. Wi, J. Seo, S. G. Jeong, S. J. Chang, Y. Kang and S. Kim. Solar Energy Materials and Solar Cells, 143, pp.168-173 (2015).

60. A. O. Elsayed. Journal of Energy Storage, 4, pp.106-112 (2015).

61. K. Benson, C. B. Christensen and R. W. Burrows. New phasechange thermal energy storage materials for buildings (No. SERI/TP-255-2727; CONF-850905-5). Solar Energy Research Inst., Golden, CO USA (1985).

62. A. Castell and M. M. Farid. Energy and Buildings, 81, pp.59-71 (2014).

63. K. Nithyanandam and R. Pitchumani. Energy, 64, pp.793-810 (2014).

64. A. Sciacovelli, F. Colella and V. Verda. International Journal of Energy Research, 37(13), pp.1610-1623 (2013).

65. H. Peng, G. Ding and H. Hu. International journal of refrigeration, 34(8), pp.1833-1845 (2011)
66. A. Adil, S. Gupta and P. Ghosh. Journal of Energy, 2014 (2014).

67. J. Hone. Dekker Encyclopedia of Nanoscience and Nanotechnology, 6, pp.603-610 (2004).

68. L. Fan and J. M. Khodadadi. Journal of Heat Transfer, 134(9), p.092301 (2012).

69. A. Elgafy and K. Lafdi. Carbon, 43(15), pp.3067-3074 (2005).

70. Y. Cui, C. Liu, S. Hu and X. Yu. Solar Energy Materials and Solar Cells, 95(4), pp.1208-1212 (2011).

71. R. J. Warzoha, R. M. Weigand and A. S. Fleischer. Applied Energy, 137, pp.716-725 (2015).

72. P. Gunnasegaran, E. Sandhita, H. A. Mohammed, M. A. Jalal and N. H. Shuaib, INTECH Open Access Publisher (2012).

73. Y. Zhong, M. Zhou, F. Huang, T. Lin and D. Wan. Solar Energy Materials and Solar Cells, 113, pp.195-200 (2013).

74. C. J. Ho and J. Y. Gao. International Communications in Heat and Mass Transfer, 36(5), pp.467-470 (2009).

75. L. Jia, Y. Chen and S. Mo. International Journal of Heat and Mass Transfer, 59, pp.29-34 (2013).

76. J. L. Zeng, L. X. Sun, F. Xu, Z. C. Tan, Z. H. Zhang, J. Zhang and T. Zhang. Journal of Thermal Analysis and Calorimetry, 87(2), pp.371-375 (2006).

77. N. Sahan and H. O. Paksoy. Solar Energy Materials and Solar Cells, 126, pp.56-61 (2014).

78. F. Yavari, H. R. Fard, K. Pashayi, M. A. Rafiee, A. Zamiri, Z. Yu, R. Ozisik, T. Borca-Tasciuc and N. Koratkar. The Journal of Physical Chemistry C, 115(17), pp.8753-8758 (2011).

79. X. Li and D. Zhu. Mater Rev, 23(3), pp.11-16 (2009).

80. M. Mehrali, S. T. Latibari, M. Mehrali, T. M. I. Mahlia, E. Sadeghinezhad and H.S.C. Metselaar. Applied Energy, 135, pp.339-349 (2014).

81. Y. Fang, S. Kuang, X. Gao and Z. Zhang. Journal of Physics D: Applied Physics, 42(3), p.035407 (2008).

82. J. MacMullen, Z. Zhang, J. Radulovic, C. Herodotou, M. Totomis, H. N. Dhakal and N. Bennett. Energy and Buildings, 52, pp.86-92 (2012).

83. R. D. Weinstein, T. C. Kopec, A. S. Fleischer, E. D'Addio and C.A. Bessel. Journal of Heat Transfer, 130(4), p.042405 (2008).

84. X. L. Wang, X. Q. Zhai, T. Wang, H. X. Wang and Y. L. Yin, Applied Thermal Engineering, 58(1), pp.252-260 (2013). 